\title{
THE GROWTH OF ANTI-CORRUPTION ATTITUDES IN CZECH MARKETING COMMUNICATION AND PR ANTI-CORRUPTION FIGHT AS MARKETING TOOL
}

\author{
Kasl Kollmannová, D.
}

\section{Executive summary}

This article analyzes the emergence of a new trend in marketing communication and PR in the Czech Republic. After the decline of public trust after the economic crisis in 2008, many state officials and politicians were blamed for corruption and fraud worldwide (Edelman, 2013). Anti-corruption attitudes have emerged in government communication, media, NGOs and also within the business sector. The term "anti-corruption" has become an often-used marketing claim. Anti-corruption claims and values have been used by a wide range of companies and institutions in their corporate communication or PR. Often, the main business leader serve as personalities and opinion leaders in anti-corruption activities; these include individuals such as Karel Janeček, Stanislav Bernard or Radim Jančura. This article analyzes and discusses embedding anti-corruption attitudes within the marketing communication and PR strategy and possible impacts on the reputation of the company's management.

JEL Classification: M14

Keywords: Anti-corruption; marketing communication; social responsibility; public relations; reputation management

\section{Introduction}

Anti-corruption emerged within the Czech society soon after adoption of the democratic system; however, it became a hot topic only after 2008 - the economic crisis, which is also called the crisis of trust. As previous research has shown, for Czech CEO's, trust is an essential line of their business, "combined with a transparent entrepreneurship and the image of 'good will' represented by a non-ostentatious lifestyle, CSR programs or ethical marketing is becoming a more important part of the corporate communication" (Kasl Kollmannová, 2012).

Czech marketing communications have been described mainly by Karlíček and others (Karlíček \& Král, 2011, Karlíček, 2013). Within Czech companies, sales departments rule in the overall strategy of the company (55\%), as opposed to only $22 \%$ in the case of the marketing department, and $14 \%$ for financial departments. Globalization effects are significant; for example, the strong influence of global companies and global marketing communication affect the characteristics of domestic organizations. Forty percent of all companies are following the rules of headquarters; however $24 \%$ of them say they are very independent (Millward Brown, 2011). Despite the global trends in the Czech marketing communications, we can define characteristics, which seem to be local or regional-based, like the popularity of retro-marketing brands such as Kofola or Botas, local modern outdoor brands such as Hannah or Bushmann or the rise of anti-corruption attitudes after 2008.

\section{Methodology}

The aim of this study is to prove or disapprove the hypothesis that the anti-corruption issues have emerged in Czech marketing communication and PR of private companies, joint-stock companies or NGOs after the crisis in 2008. The research will use the quantitative content analysis of selected media formats (Berelson 1971), analysis of available secondary data and marketing communication analysis of selected organizations.

\section{Corruption fight as new trend in media and society}

Corruption emerged as a main issue of government communication in the Nečas administration and was also set by many media as the primary agenda. According to GfK research from October 2009, which analyzed the corruption and corruption climate in the Czech Republic, 74\% of Czech people do not agree with corruption and see it as amoral; however, the number of people who do think so has sunk $11 \%$ in the past decade. Moreover, the level of general 
Table 1 Would you be willing to participate in an anti-corruption fight?

\begin{tabular}{|l|c|c|c|c|c|c|c|}
\hline Year & $\mathbf{1 9 9 8}$ & $\mathbf{1 9 9 9}$ & $\mathbf{2 0 0 1}$ & $\mathbf{2 0 0 2}$ & $\mathbf{2 0 0 3}$ & $\mathbf{2 0 0 6}$ & $\mathbf{2 0 0 9}$ \\
\hline Yes & $31 \%$ & $39 \%$ & $30 \%$ & $34 \%$ & $34 \%$ & $30 \%$ & $32 \%$ \\
\hline No & $52 \%$ & $53 \%$ & $55 \%$ & $54 \%$ & $53 \%$ & $52 \%$ & $61 \%$ \\
\hline I don't know & $17 \%$ & $8 \%$ & $15 \%$ & $12 \%$ & $13 \%$ & $18 \%$ & $7 \%$ \\
\hline
\end{tabular}

Source: GfK, 2009

acceptance of corruption norms has increased significantly (GfK, 2009). Between 1998 - 2009, the number of people who admitted they give bribes rose by $10 \%$, while only $51 \%$ of people claimed they never give bribes. The number of people who claimed that they received bribes in the past year also rose to $48 \%$ in 2009 compared to $36 \%$ (GfK, 2009). Eighty-two percent of respondents in the GfK research stated that corruption is a matter of state and not its citizens and that the state should also fight corruption. The citizens willing to participate in fighting corruption also declined, falling from $39 \%$ in 1999 to $30 \%$ in 2006 (see table below).

As we have seen above, people's attitudes toward corruption have changed towards more acceptance of such a practice as the norm. The high level of corruption (either perceived or real) is linked with the decrease of public trust of various institutions: either governmental or business. Corruption and fraud emerged as a main issue as a consequence of the loss of public trust, followed by the economic crisis in 2008 (Edelman, 2013). The concept of "public trust" or "trust of publics" has been analyzed mainly by German scholars Niklas Luhmann (1973) and Günter Bentele (Bentele 1994, Bentele - Seidenglanz, 2005). The level of trust - based on media representation and public perception - clearly affects organizations and their profitability, as analyzed by Vercic (2000) and Chander (2003). As we see in the graph below, corruption and fraud globally lead the reasons for distrust in business and government in general.

In comparison of global and Czech data from the same research (compare Graph 1 and 2), we can see a significant difference. Corruption and fraud are quoted by the vast majority of informed publics to be the reason for distrust in government, but in $38 \%$ of the cases, also in the business sector. Czech people, however, undermine the "transparency" - these issues are problem locally only for $3 \%$ of respondents. This

\section{Graph 1 Corruption/fraud as a reason for distrust in business and government - global}

REASONS FOR DECREASED BUSINESS AND GOVERNMENT TRUST (AMONG THOSE WHO REPORTED TRUSTING BUSINESSOR GOVERNMENT LESS OVER THE PAST YEAR)

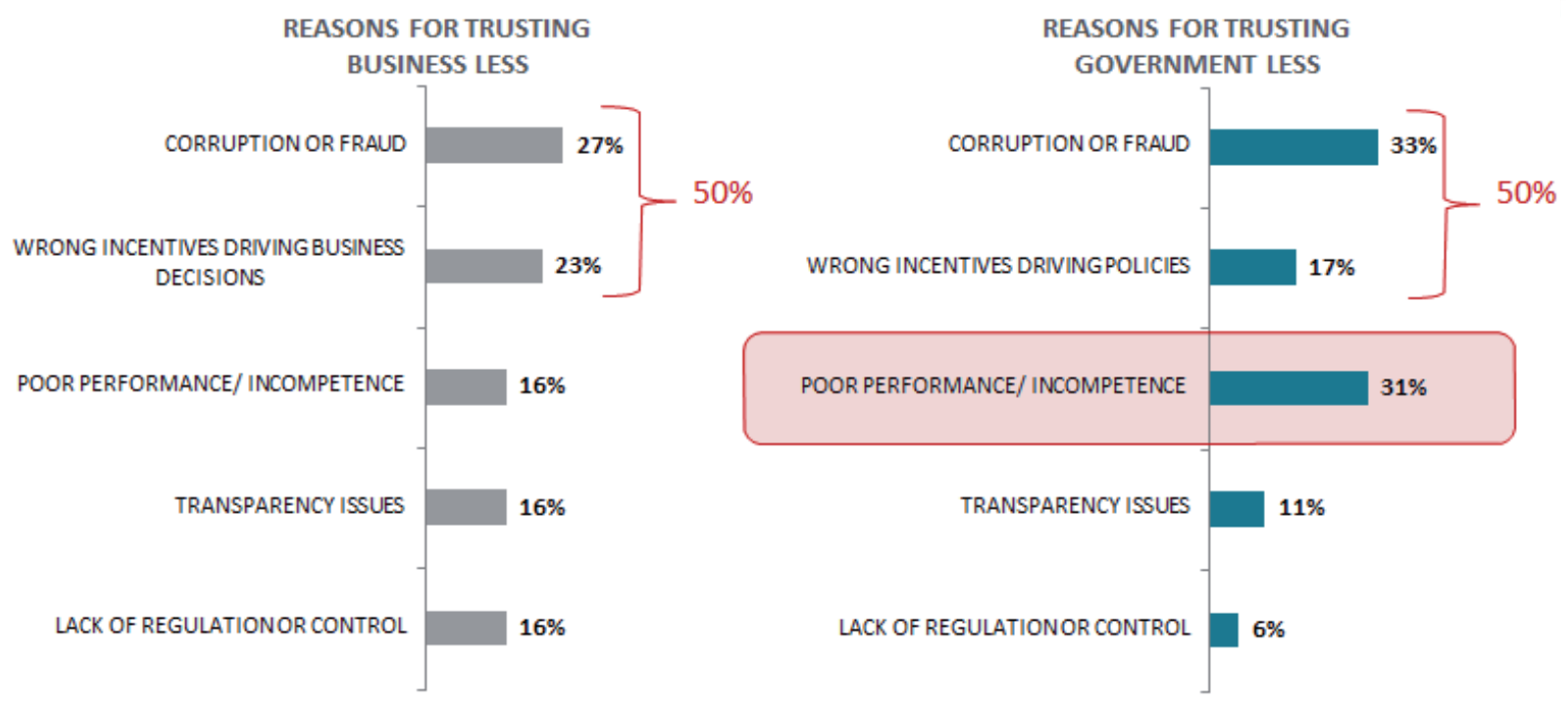

Source: Edelman, 2013 
Graph 2 Corruption/fraud as a reason for distrust in business and government - Czech Republic

\section{CZECH REPUBLIC}

REASONS FOR DECREASED BUSINESS AND GOVERNMENT TRUST

(AMONG THOSE WHO REPORTED TRUSTING BUSINESSOR GOVERNMENT LESS OVER THE PAST YEAR)
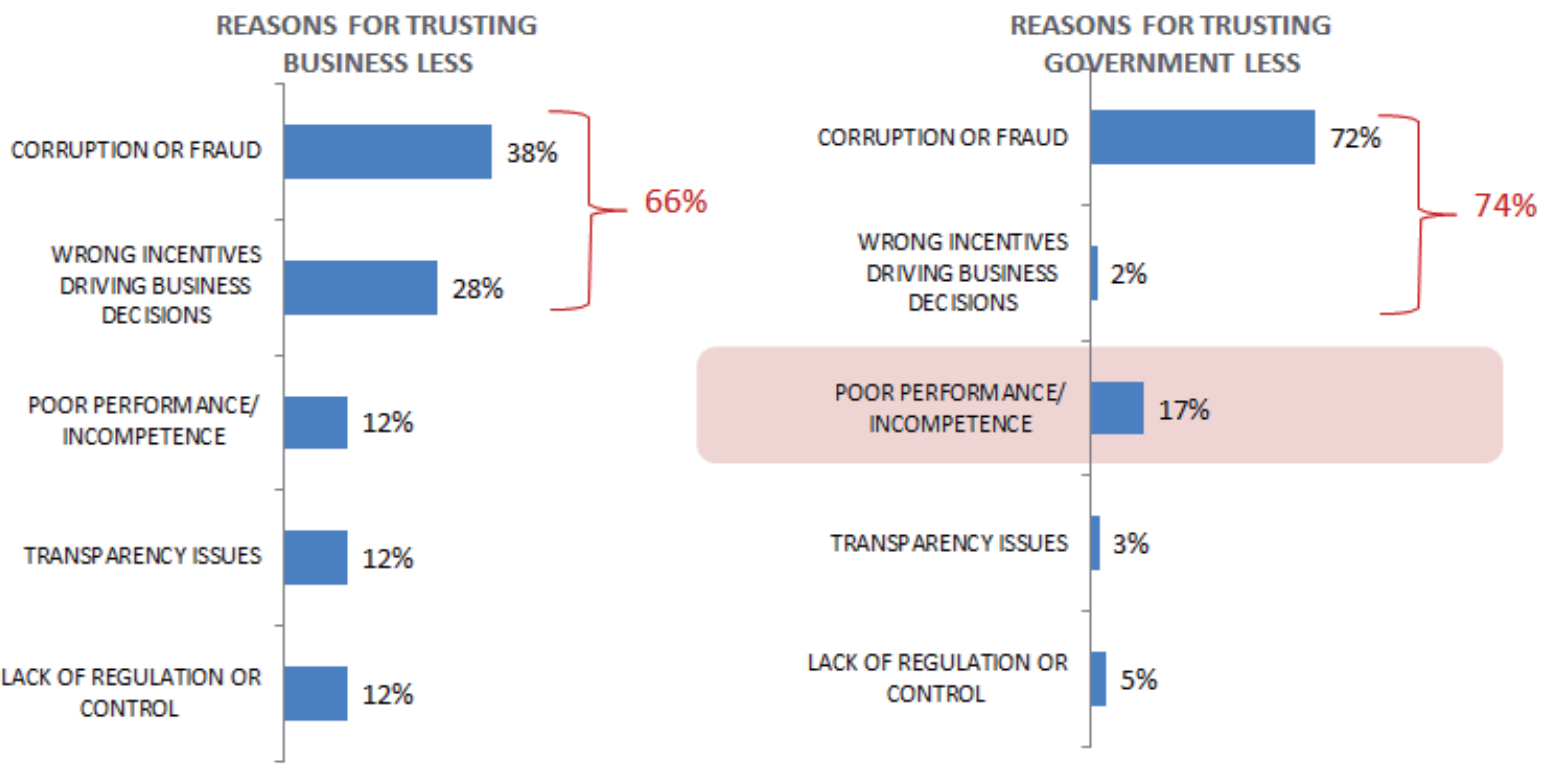

Source: Edelman, 2013

Graph 3 Development of corruption and anti-corruption issues in Czech media 2005-2012

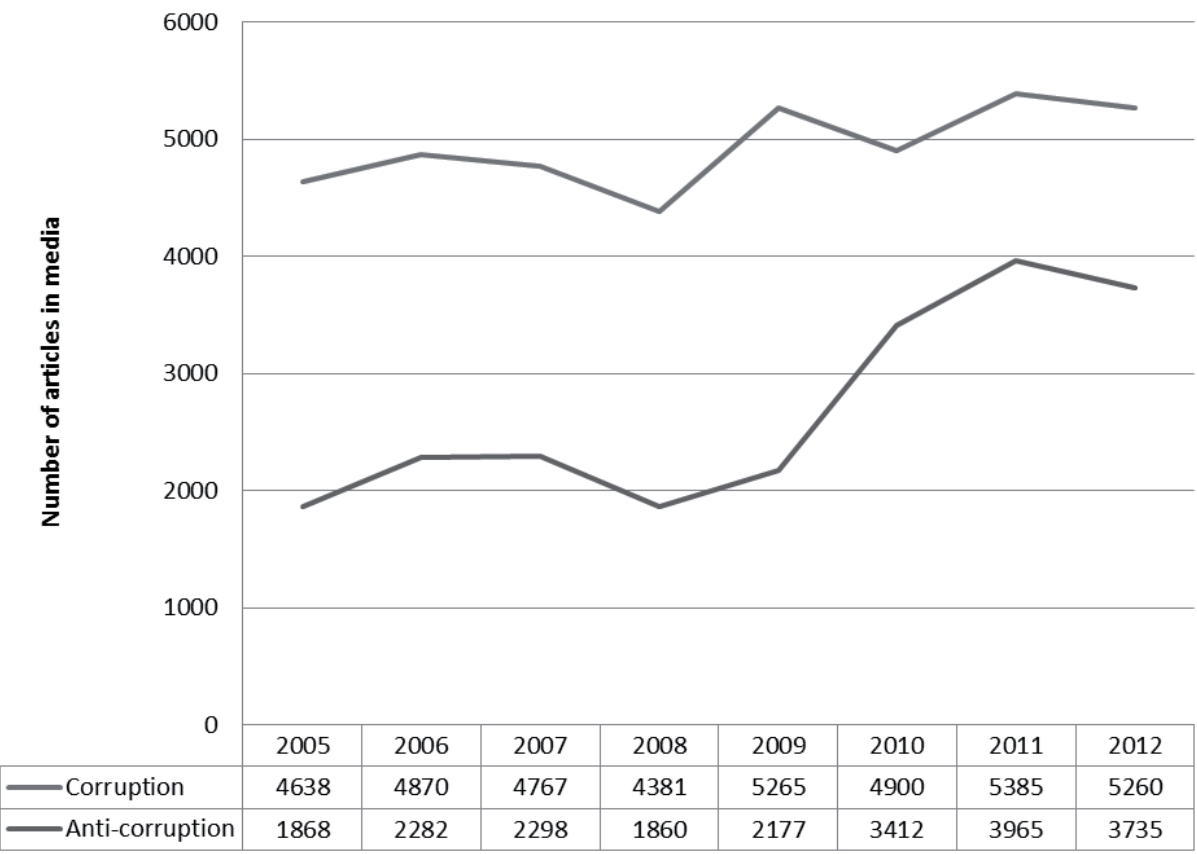

Source: Own analysis, 2013. 
discrepancy clearly shows that instead of increasing "transparent behavior" of corporations and companies, Czechs prefer to talk about "anti-corruption" attitudes.

When we have a look in the media, we can see a clear trend of rising anti-corruption issues from year 2009 onwards. We analyzed the quantitative appearance of articles in the main Czech media (newspapers, TV and radio with the exception of online servers and local media) for variables "corruption" and "anti-corruption".

Whereas the appearance of "corruption" issues has increased slightly between 2005-2012, the "anti-corruption" issues have risen significantly between 2009-2012 - i.e. they more than doubled. An anti-corruption attitude has become a hot topic, or a so-called "buzz-word" and popular cultural meme (Oxford Dictionary, 2013).

A so-called "Anti-corruption movement" appeared in the Czech Republic more visibly after 2009, when companies and NGOs embedded the anti-corruption rhetoric and values in their marketing communication. Among companies or institutions using anti-corruption as a buzz-word for their strategy or PR were namely:

1. NGOs: Transparency International, Janeček's National Fund Against Corruption, Z-Index, etc.

2. Private or shareholder companies which declare their anti-corruption statements in their corporate values or CEO images: Student Agency, Bernard, Linet, Unicorn, etc.

3. Anti-corruption as a business plan: Corrupt Tour.

The following examples will analyze a typical company or organizational focus on anti-corruption and transparency issues.

\section{Anti-corruption values in social marketing: Karel Janeček}

Karel Janeček (RSJ company founder and CEO) became a well-known business leader mainly though his anticorruption and moral statements. RSJ is one of the world's largest algorithmic traders currently trading in London (NYSE Liffe), Chicago (CME), and Frankfurt (Eurex), based in Prague (RSJ, 2013). In 2012, he and others started an NGO project, Positive Evolution. Karel Janeček is thus the main "face" and opinion leader. In 2012, Janeček launched a massive advertising campaign, called "Waves of Evolution", with simple print advertisements featuring claims like "Don't be afraid of the truth", "When people see a positive example, they'll catch up", "Whose life have you enriched today?" etc. The campaign aggregated more than 40,000 Facebook fans, but the estimated cost was probably around 30 million CZK (1.5 mil. USD, own estimate). The campaign was criticized as pseudo-philosophical, unclear, or as a social-engineering attempt (Koutník, 2012a). RSJ promotes a variety of articles presenting Karel Janeček as RSJ's CEO talking about leadership and anti-corruption values in society (e.g. "Karel Janeček: There is more robbery here in the Czech Republic than in Ukraine, we're a corruptionist world power!", in interview for Finmag, see RSJ, 2013). Among RSJ's four major social responsibility projects is the joint project of several companies "Business without corruption", led by another Czech CEO, Martin Hausenblas.

In 2011, Karel Janeček together with Stanislav Bernard (Bernard CEO, see below), Karel Randák, a former state official, Radim Jančura, CEO of Student Agency (a transportation company) and popular actor Jan Kraus started "Nadační fond proti korupci" (NFPK), a "Foundation against Corruption", which aims to fight corruption and reveal corruption information and cases in the Czech Republic. NFPK is supported also by other Czech businessmen, such as Jannis Samaras (Kofola) or Libor Winkler (RSJ).

\section{Anti-corruption in advertising and corporate culture: Bernard Brewery}

This case will focus on the advertising campaign by Czech brewer Bernard, a company owned by Stanislav Bernard, Josef Vávra and Duvel Moortgat (strategic partner from Belgium since 2001) (Bernard, 2013). The positioning of the main product is locally produced beer which aims to become a brand icon, where the image of CEO Stanislav Bernard is pictured also visually. The positioning is based on integrated marketing communications, with several award-winning internal communications (e.g. own magazine Vlastní cestou) and also by a specific advertising campaign. The campaign is long-run with the main slogan "The world's gone crazy, keep calm".

The campaign, running since 2004, comments on current socio-political issues. In 2010, one of the billboards featured the slogan "Prague?" with golden coins, referring to the corruption and clientelism at the local city office (Bernard, 2013). Stanislav Bernard is presented as the main face and opinion leader and he's often present at many conferences or media features where he vocalizes his anti-corruption mission and values, such as at NFPK.

\section{Anti-corruption as a business plan: Corrupt Tour}

Corrupt Tour represents an example of a joint-stock company, which took the concept of anti-corruption in its own business plan, which serves as a core mission of its entrepreneurship. Corrupt Tour is a professionally managed travel agency, which offers a special kind of travelling experience ("first of its own worldwide"), opening a "new segment 
Picture 1 Bernard's Advertising Billboard, Prague, 2010-11

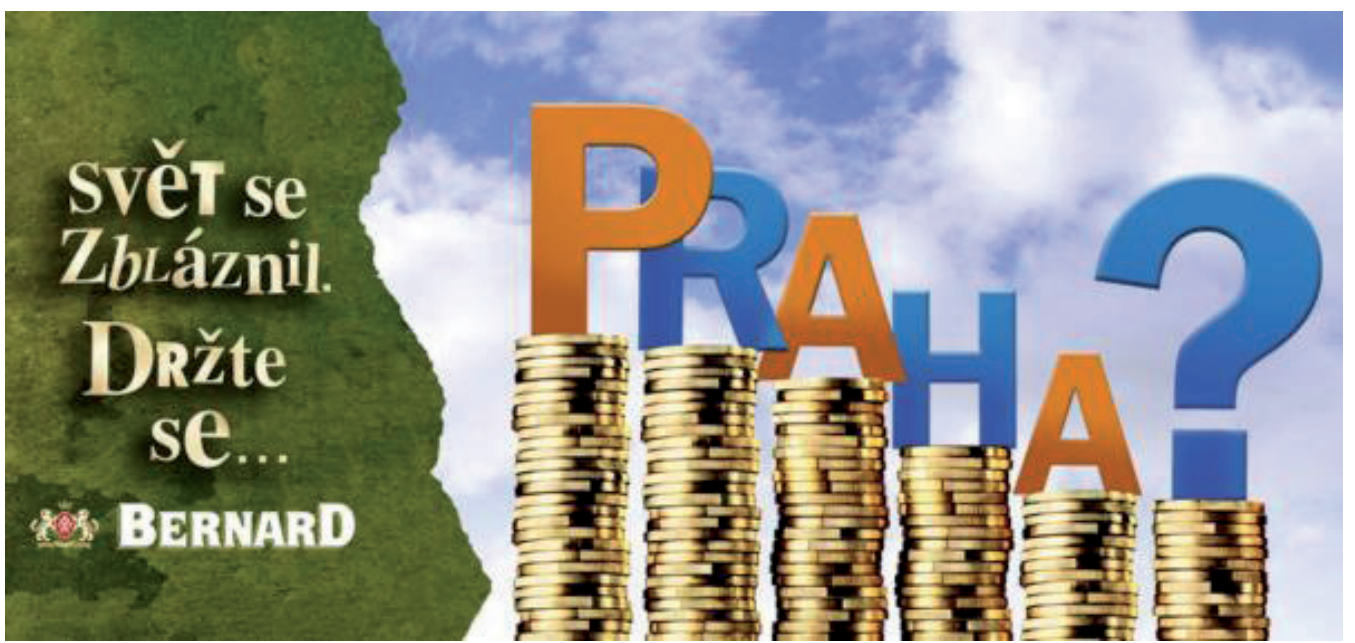

Source: http://www.bernard.cz/cs/v-akci/reklamni-kampane/4.shtml

of tourism industry" (Corrupt Tour, 2013). The shareholders are anonymous, because "joint-stock companies with anonymous shares make twice as much money than companies with transparent holders, so Corrupt Tour wants to make more money as well" (Corrupt Tour, 2013). The shares are promoted via an advertising campaign with the main claim "Make Money from Corruption - Buy Shares in Corrupt Tour" (Corrupt Tour, 2013).

The company itself is not as humorous and sells real products - e.g. bus trips focusing on corruption sightseeing, such as villas of the local bosses, the infamously overpriced Blanka tunnel or bus trips to Northern Bohemia, infamous for its corruption level. Again, Corrupt Tour is led by Petr Šourek, who is profiling himself as an opinion leader and is, to some extent, present at conferences, social events and media (Koutník, 2012b).

\section{Results}

The aim of this article was to analyze and show examples of how "anti-corruption" rhetoric is used in Czech marketing and corporate communication. Three forms of "anti-corruption" rhetoric usage were distinguished:

1) "anti-corruption" in the non-governmental sector, corporate social responsibility or social marketing, where the cases of RSJ and Positive Evolution were shown;

2) "anti-corruption" as an issue in the advertising campaigns and marketing communication of private companies as a form of brand building and strategic reputation management, such as in the case of Bernard Brewery;

3) and lastly "anti-corruption" as a core of entrepreneurship and business plan, as it is used by the travel agency
Corrupt Tour.

However, the term "anti-corruption" is not easy to define. Evidently, according to the data shown above, there is no clear definition of what "anti-corruption" and "transparency" mean to Czechs. In Czech politics, the meme "Anti-corruption fight" is often used as a substitution to politics (Kubát, 2013, p. 106). The level of corruption is often measured by the Corruption Perception Index by Transparency International (2013), yet deeper discussion about the term itself, its connotations and meaning would be much needed. Indeed the Czech Republic shows an example that the term itself can serve as a popular meme and somehow fashionable symbol, which can be used effectively in marketing communication, CSR, reputation or brand management.

\section{Managerial implications}

As shown above, anti-corruption attitudes have become trendy in the years since the global economic crisis. It has become a hot topic in the media and also a popular claim in marketing communications of selected Czech companies and NGOs. The reasons for choosing anti-corruption attitudes can differ. But for sure they support the credibility of companies as well as enhance the credibility of the business sector at large. Compared to global data, Czech distrust of both government and business is clearly linked to the suspicion of corruption and fraud. Therefore Czech companies should concentrate on increasing the level of trust by providing transparent communication, but they should be aware that "anti-corruption" has become a popular hash-tag, and its popularity can decrease if its promises or content are not fulfilled. 


\section{References}

Bentele, G., Seidenglanz, R. (2005). Vertrauen und Glaubwürdigkeit. In Handbuch der Public Relations: Wissenschaftliche Grundlagen und berufliches Handeln. Mit Lexikon, ed. Bentele, G., Fröhlich, R., Szyszka, P. Wiesbaden: Verlag für Sozialwissenschaften, 346-360.

Bentele, G. (1994). Öffentliches Vertrauen: Normative und soziale Grundlage für Public Relations In Normative Aspekte der Public Relations: Grundlagen und Perspektiven. Eine Einführung, ed. Armbrecht, W., Zabel, U. Opladen: Westdeutscher, 131-158.

Berelson, B. (2008). Content Analysis in Communcation Research. New York: Hafner.

Bentele, G. (2008). „Trust of Publics.“ In The International Encyclopedia of Communication, ed. Donsbach, W. Oxford: Blackwell Publishing, 2008.

Berger, P. L., Luckmann, T. (1966). The social construction of reality: A treatise in the sociology of knowledge. New York: Doubleday Anchor.

Bernard (2013). Bernard Online, accessed 12, 2013, [available at http://www.bernard.cz/cs/story/pivovar.shtml].

Chander, A. (2003). A constructive design methodology for trust management systems. Stanford: Stanford University Press.

Corrupt Tour (2013). Corrupt Tour Online. accessed March 12, [available at http://corrupttour.com/].

Edelman (2013). Trustbarometer 2013, accessed March 19, 2013, [available at http://www.edelman.com/ trust-downloads/global-results-2/].

Karlíček, M, Král, P. (2011). Marketingová komunikace. Prague: Grada.

Karlíček, M. (2013). Základy marketingu. Prague: Grada.

Koutník, O. (2012a). Karel Janeček na naivních vlnách? Česká Pozice, accessed March 16, 2013, [available at http://www.ceskapozice.cz/domov/politika/ karel-janecek-na-naivnich-vlnach].

Koutník, O. (2012b). Nová cestovka Corrupt Tour: Výlety na místa českých korupčních kauz. Česká Pozice,, accessed March 16, [available at http://www.ceskapozice. $\mathrm{cz} /$ domov/politika/nova-cestovka-corrupt-tour-vylety-namista-ceskych-korupcnich-kauz].
Millward Brown (2011). Anatomie českého marketéra. Accessed March 13, 2013, [available at http://www.slideshare.net/bebech/ prezentace-anatomie-ceskeho-marketera-toplines].

Oxford Dictionary (2013). "Meme". In Oxford Dictionary, accessed March 12, 2013, [available at http://oxforddictionaries.com/definition/english/meme?q=meme].

RSJ (2013). Online, accessed March 19, 2013, [available at http://www.rsj.com/en/].

Transparency International (2013). Corruption Perception Index, accessed March 12, 2013, [available at http://cpi. transparency.org/cpi2012/].

Vercic, D. (2000). Trust in organizations: A study of the relations between media coverage, public perception and profitability. Ph.D. dissertation, London: London School of Economics and Political Science.

Vlny evoluce (2013). Kolik nás je, accessed March 16, 2013, [available at http://www.vlnyevoluce.cz/\#vlna-12/koliknas-je.html].

Mravec, M. (2010). Korupční klima v České republice. GfK research, accessed March 12, 2013, [available at http:// www.transparency.cz/doc/projekty/NIS/Konference/ Martin Mravec_GfK Korupcni_klima_v_Ceske_republice.pdf].

Kasl Kollmanová, D. (2012). CEO and Businesses are Losing Trust: Comparison of EU, USA, Czech and Slovak Republic. Central European Business Review, 1(1): 7-13.

\author{
Author \\ PhDr. Denisa Kasl Kollmannová, Ph.D. \\ Head of Department \\ Marketing Communication and Public Relations \\ Faculty of Social Sciences \\ Charles University in Prague \\ Smetanovo nábřeží 6, 11000 Praha 1 \\ kollmannova@fsv.cuni.cz
}

